\title{
ASSESSING AND EVALUATING THE GENERAL LEGAL CHARACTERISTICS OF WAR CRIMES: A BASIC NECESSITY OR A CONFUSED PLATFORM
}

VALORACIÓN Y EVALUACIÓN DE LAS CARACTERÍSTICAS JURÍDICAS DE LOS CRÍMENES DE GUERRA: UNA NECESIDAD BÁSICA O UNA BASE CONFUSA

\author{
Hennadii Yevhenovych Bershov* \\ Oksana Anatolyevna Hrytenko** \\ Vadym Heorhiiovych Khashev ${ }^{* * *}$ \\ Mykhailo Ihorevych Fialka****
}

\begin{abstract}
The general legal characteristics of war crimes allow to comprehensively study the indicated acts, to understand their essence, which in turn should facilitate and improve the quality of criminal qualification of criminal offenses against performing the established procedure of active service. The need to form general legal characteristics of war crimes is due to the fact that the sphere of public relations related to active service is intersectoral, since it is simultaneously regulated by the norms of various branches of law. The authors have found out the main features of war crimes
\end{abstract}

\footnotetext{
* Ph.D. in Law. Judge of the Second Administrative Court of Appeal. https://orcid.org/00000002-3439-5544. bershov.ge@gmail.com

** Doctor of Law. Associate Professor. Professor of the Department of Criminal Law Disciplines of the Educational and Scientific Institute of Law and Innovative Education of the Dnipropetrovsk State University of Internal Affairs (Dnipro, Ukraine). https://orcid.org/0000-0003-1376-6956. oksanochka.oksi78@ukr.net

${ }^{* * *}$ Ph.D. Associate Professor. Associate Professor of the Dnipropetrovsk State University of Internal Affairs (Dnipro, Ukraine). https://orcid.org/0000-0002-2240-0713.

khvg7747@gmail.com

**** Candidate of Law. Associate Professor. Associate Professor of the Department of Criminal Law and Criminology of the Faculty No. 1 of the Kharkiv National University of Internal Affairs (Kharkiv, Ukraine). https://orcid.org/0000-0001-5599-3335.

fialkami70@gmail.com
} 
and have carried out their characteristics by determining the specific features of their regulation both by criminal and other branches of law. The authors have provided an analytical basis for this in order to evaluate the provisions of regulatory legal acts regulating the procedure of active service and determine the main features of war crimes. The findings of the research was that war crimes infringe the statutory order of performing active service, and the subjects of such illegal acts are military personnel, persons liable to military duty and personnel with reserve obligations during the battle assembly. The general legal characteristics of war crimes is formed taking into account criminal and legal features of the specified criminal offenses and defines specific features of active service; the established procedure for performing active service; military personnel, persons liable to military duty and personnel with reserve obligations during the battle assembly as subjects of crime.

Keywords: War Crimes, Military Crimes, Criminal Offenses, Active Service, Criminal and Legal Features, Criminal and Legal Protection

Resumen: Las características jurídicas generales de los crímenes de guerra permiten estudiar integralmente los actos señalados, para comprender su esencia, lo que a su vez, facilita y mejora la calidad de la calificación penal de los delitos contra la realización del procedimiento establecido para el servicio militar activo. Su necesidad se debe a que el ámbito del servicio activo es intersectorial, ya que se encuentra regulado simultáneamente por normas de diversas ramas del Derecho. Los autores describen las principales características de los crímenes de guerra y determinan las especificidades de su regulación tanto por el Derecho penal como por otras ramas del Derecho. Los autores proporcionan una base analítica con el fin de evaluar las disposiciones de los actos jurídicos reglamentarios que regulan el procedimiento del servicio activo y determinar las principales características de los crímenes de guerra. Los hallazgos de la investigación fueron que los crímenes de guerra infringen la orden legal de realizar el servicio activo, mientras que los sujetos de tales actos ilegales son el personal militar, las personas sujetas al servicio militar y el personal con obligaciones de reserva durante la asamblea de batalla. Las características legales generales de los crímenes de guerra se forman teniendo en cuenta las características penales y legales de los delitos señalados y definen las características específicas del servicio activo; el procedimiento establecido para la prestación del servicio activo; personal militar, personas sujetas al servicio militar y personal con obligaciones de reserva durante el montaje de batalla como sujetos del delito. 
Palabras clave: Crímenes de guerra, delitos militares, delitos, servicio activo, características legales y penales, protección penal y legal

Summary. I. Introduction. II. Research Methodology. III. The Problem's State of Research. IV. Research Results and Discussion. V. Conclusions. References.

\section{INTRODUCTION}

One of the main tasks of a democratic, legal, social and sovereign state is to guarantee and ensure human rights, freedoms and legitimate interests. To accomplish this, it is necessary to create favorable conditions for the development of all spheres of public life, because the mechanism of human rights realization, as a rule, is effectively functioning in economically developed countries. In particular, an important area is ensuring the sovereignty of the state, national security, as well as public safety and order. Achieving the indicated task depends on a large number of factors, where we should single out the organization and ensuring the compliance with the established procedure of performing active service. The outlined sphere of public relations plays one of the key roles in "protecting the Homeland, independence and territorial integrity of Ukraine" (On General Military Duty and Military Service), which, in turn, is the constitutional duty of any citizen of Ukraine. In particular:

(i) The Article 3 of the Constitution of Ukraine emphasizes that «the human being, his or her life and health, honor and dignity, inviolability and security shall be recognized in Ukraine as the highest social value».

(ii) The Article 17 emphasizes that «protecting the sovereignty and territorial integrity of Ukraine, ensuring its economic and information security shall be the most important functions of the State and a matter of concern for all the Ukrainian people».

(iii) The Article 65 stipulates the obligation of a citizen of Ukraine to defend the Motherland, independence and territorial indivisibility of Ukraine, respect for its state symbols, and establishes that citizens must perform military service in accordance with the law.

Besides, the Constitution of Ukraine states that:

«The defense of Ukraine and protection of its sovereignty, territorial integrity and inviolability shall be entrusted to the Armed Forces of Ukraine. Ensuring the security of the State and protecting the State borders of Ukraine shall be entrusted to respective military formations and law enforcement bodies of the State, the organisation and operational procedure of which shall be determined by law. The Armed Forces of Ukraine and other military formations shall not be used by anyone 
to restrict the rights and freedoms of citizens or with the intent to overthrow the constitutional order, subvert the government authorities or obstruct their activities. The State shall ensure social protection of citizens of Ukraine who serve in the Armed Forces of Ukraine and other military formations as well as members of their families. The establishment and operation of any armed formations not envisaged by law shall be prohibited in the territory of Ukraine. The location of foreign military bases shall not be permitted on the territory of Ukraine».

It is noticeable from the above that active service is an integral part of the activities on ensuring the protection of independence and territorial integrity of Ukraine, which takes place exclusively in the manner and on the grounds established by law. Violations of public relations in this area lead to consequences that are particularly dangerous. In this regard, the procedure of active service is under criminal law protection, which is represented by the system (complex) of means (criminal law and criminal and legal policy) that provide protection, in this case the procedure of active service, focusing the efforts on the fact that the analyzed relations (taken under the protection of criminal law) remain, as a rule, objects of protection and are the least subjected to possible criminal illegal encroachments (Matviichuk, 2008, pp. 2-4). Moreover, the system of criminal and legal protection, in particular the procedure of active service, includes criminal and legal norms (prohibitive, explanatory, encouraging and restrictive) and methods of criminal and legal policy (criminalization, decriminalization, penalization and depenalization), which assist to transfer standardization into the arrangement of social relations (Kuznetsov, 2015, p. 109). However, the provision of proper criminal and legal protection of the procedure of active service, as well as timely detection of criminal illegal encroachments in the specified area of public relations and their effective pre-trial investigation is impossible without understanding the nature and features of military criminal offenses, awareness of general legal aspects of their characteristics. In this context, the provision of general legal characteristics of war crimes seems to be an important area of research.

The scientific novelty of the research is the fact that authors have carried out the general legal characteristics of war crimes taking into account the features of criminal offenses against the established procedure of performing active service.

The purpose of this article is to provide the general legal characteristics of war crimes. In accordance with the set purpose. The objectives of the research are as follows: to study scientific approaches to determining the nature and content of war crimes; to single out and to highlight specific features of the structural elements of illegal actions against 
the procedure of active service; to form author's interpretation of the definition of war crimes.

\section{RESEARCH METHODOLOGY}

The dialectical method of cognition assisted to establish specific features of the formation of the legal definition of war crimes and to clarify the features of criminal offenses against the established procedure of active service within their relationship. Methods of logic were used to carry out an in-depth analysis of legal provisions and scientific positions to determine the nature and content of war crimes, the characteristics of their features that allow us to distinguish them out of related illegal actions. In addition, the comparative and legal method assisted to compare specific features of the regulation of the procedure of active service and to determine the composition of relevant offenses by regulations of normative and legal acts of various branches of law, including the norms of international criminal law and criminal law of Ukraine. Features of war crimes, which allowed us to carry out their general legal characteristics, were singled out by using the system and structural method. Great and fantastic method of understanding the phenomenon and efficiency of aspect of war crimes regulations, but the question we should be posing is by finding out how effective are these methods when we continue to experience violations of war crimes by some certain individual who are supposed to respect the basic tenets and principles of war crimes. There is no way we can be talking about regulating war crimes, and the same time experiencing constant violations. One thing is to establish good laws, policies, regulations to handle issues of war crime, the other is in ensuring the implementation and application of these principles and policies. Well this has remain and continue to remain a common thorn in the realm of war crimes and other related criminal offences.

\section{THE PROBLEM'S STATE OF RESEARCH}

The procedure of active service and violations in this area have been repeatedly studied in scientific works by both domestic and foreign scholars in various aspects. In particular, V. V. Sokurenko (2015) has comprehensively studied the problems of public administration in the defense sector of Ukraine. M. V. Kushnir (2018) analyzes theoretical and legal principles of the administration of active service in the Armed Forces of Ukraine, improvement of the system of state military and administrative 
management in the field of military and service relations related to the effectiveness of career advance of commissioned staff; clarifies the characteristic features of the mechanism of administration and its role in the process of active service in the Armed Forces of Ukraine taking into account the experience of military and service administration of NATO Member States (p. 133).

V. Koval (2021) clarifies the administrative and legal status of military personnel in Ukraine under the legal regime of martial law. The legislative regulation of the administrative and legal status of servicemen in Ukraine is studied in the work. The paper analyses the main directions of transformation of the administrative and legal status of servicemen under the legal regime of martial law and identifies the following three areas, namely pre-transformation, competent and elemental.

M. O. Akimov (2019), M. V. Voznyk (2019), V. Zhurovets (2019), V. Z. Kurys (2019), V. M. Tereshchuk (2019), B. M. Shakhrai (2019), S. V. Sheshko (2019) have studied the issue of violation of the procedure of active service, including military criminal offenses; some aspects of improving the military legislation of Ukraine; specific features of proper criminal and legal assessment of violations of the laws and customs of war; legal guaranteeing of military discipline and public order; legal guaranteeing of military formations in Ukraine; the role of the judicial agencies in guaranteeing the rights and freedoms of military personnel and keeping law and order in the armed forces and other military formations of Ukraine; problems of improving the legal status of the subjects of public administration of the national security and defense sector of Ukraine; legal principles for the functioning of the security and defense sector, etc.

Theoretical and applied aspects of war crimes, criminal and legal, criminological and forensic characteristics of military criminal offenses have been the subject matter of scientific research in the works of such scholars as Ya. S. Kulkina (2016), M. I. Karpenko (2019), T. B. Nikolaienko (2019), M. Z. Lutsiv (2020), and T. S. Sadova, et al. (2021).

The thesis of M. Piddubna (2020) is devoted to the investigation of issues of the implementation of international criminal law norms on military offences into the national criminal legislation of Ukraine. The author concludes that the chapter of the Criminal Code of Ukraine on military offences shall include articles determining the concept of military offence, principles of liability for military offences, list of persons, who shall be the subjects of military offences, as well as general provisions on the liability for military offences. In order to implement the provisions on military offences into the Criminal Code of Ukraine, the author considers it appropriate to amend part 2 of Article 438 of the Criminal Code of Ukraine 
with following qualifying features: that caused grievous bodily harm; in combination with sexual offences; that caused the pregnancy of a victim. The author also proposes to exclude the action «cruel treatment of prisoners of war or civilians» from the disposition of Part 1 of Article 438 of the Criminal Code of Ukraine. Besides, to implement the liability for military offences committed by a commander (senior officer) or a person authorized to give orders, instructions or directives, the author proposes to implement a separate article, which would establish the grounds for such liability. It is also proposed to provide liability for hostage-taking while armed conflict.

S. O. Karytonov (2019) concept of military crimes has been formulated, concept of these crimes has been defined, their general characteristics have been given, taking into account objective and subjective signs, and a theoretical model of these crimes has been developed. Legal nature of «military crimes» concept and specifics of its main features: public danger, wrongfulness, guilt and punishability were researched at the same time, by using general scientific research methods interaction of concepts «military crimes» and «elements of a military crime» was analyzed.

Ye. M. Pashchenko (2021) enunciates a number of conceptions, conclusions and suggestions that are new in conceptual terms and important for the practice of such criminal type of prevention. Based on the complex criminological grounds, military violent crimes are classified into following types:

(i) Crimes against life and health, honor and dignity of servicemen: violation of the statutory rules of relationships between servicemen in case of insubordination, violation of the weapons handling rules, as well as 8 substances and objects, which pose an increased threat to the environment, violation of the statutory rules of the guard service or patrol, violation of the rules of border service, violation of the rules of combat duty, violation of the statutory rules of internal service, criminal actions of a serviceman who is in captivity.

(ii) Crimes against life and health, honor and dignity of others: violence against the citizens in the area of hostilities, ill-treatment of prisoners of war, looting.

(iii) Violent crimes against military commanders: disobedience; resistance to the boss or forcing him to violate official duties, threat or violence against the boss.

(iv) Violent crimes of military commanders: official authority abuse by a military official.

W. Fenrick (2015), W. L. Cheah (2018a; 2018b) provide characteristics of war crimes as a kind of international crimes. The article of A. Onyskiv (2016) deals with the relation of war crimes against the order of 
military service with other crimes. The ratio related offenses typical for unauthorized abandonment of a military unit or duty station and desertion; evading military service by self-mutilation or otherwise, and dodging conscription for military service, military service officer's persons. The ratio of general and special competition rules is typical for unauthorized abandonment of a military unit or place of service and unauthorized abandonment of the battlefield. The concept of war crimes through the prism of the revisionist theory of just war is formed by A. Chehtman (2018).

Certain aspects of criminalization and their impact on the formation of the legal interpretation of the concept of "war crimes" are determined by E. Aaronson and G. Shaffer (2021). The structure of war crimes, in particular their material elements, is distinguished by D. Marchesi (2021).

Not denying the significant contribution of these scholars in solving the problems related to the legal regulation and legal principles of active service, as well as defining the concept of war crimes, distinguishing and characterizing their features, it should be noted that there are many unresolved or controversial issues in this area. All the authors above have been of great help by establishing that they exist a fundamental clue affecting aspect of war crimes, but our problem does not only remain at the level of establishing or identifying the basic problems, but our problem also here is in looking out for a plausible solution which will curb the continuous experienced of war crimes in Ukraine. The rampant violation of this crime by some military personnel all in the name of maintaining the country peace and security has been worrisome as it becomes a constant melody that they are combatting war crimes. We all understand that war crimes have been a huge bone frustrating the essence of humanity existence due to its drastic and horrible outcome, where the eradication of it will of great relieve to the international community in general and Ukraine in particular, it's continuing existence will continue too questionable.

\section{RESEARCH RESULTS AND DISCUSSION}

The war crimes trials that followed World War II marked the first major application of the judicial process to the laws of war. The establishment of the war crimes tribunals for Yugoslavia and Rwanda in the 1990's provided another opportunity to apply the laws of war and afford a unique opportunity to examine this process. Postwar development of international human rights law in the interim has changed the way in which these tribunals address war and war crimes (Fenrick, 1999). "Guilt", "responsibility" and "punishment" are notions that we all use in everyday 
language, especially in moral, religious, and legal contexts. Punishment can be a sentence prescribed by a court of law, God's punishment on Judgment Day, or the penalties doled out in the home, at school, or in other social institutions where certain rules (norms) of behavior are recognized and upheld. And similarly with "guilt" and "responsibility," which are involved wherever there is talk of punishment (Ross, 1955).

Large-scale social and political transformations and armed conflict in the south-eastern part of Ukraine which started in 2014 resulted in substantial crime rate aggravation. Total impoverishment of citizens, massive internal migration of residents of Crimea, Luhansk and Donetsk regions, growth of radicalization, illegal weapon circulation, disappointment in authority's policy and actions, citizen's frustration and lack of trust to recently reformed law enforcement structure's capacity and competence, resulted in negative changes of violent and economic crimes dynamics and structure (Akimov, 2018). Today's conditions require the creation of a legal system that can respond effectively to potential threats. Preventing and combating crimes against the foundations of national security requires an effective theoretical legal framework. In this regard, criminal law must be constantly improved, including through the making of new scientific developments. Crimes against the foundations of Ukraine's national security are the most dangerous acts that encroach on public relations, ensuring the protection of state security, the country's defense capabilities, the independence of the state, and its constitutional order. Criminal protection of these social relations is the key to the proper functioning of the state and its institutions (Yaremko, et al., 2021).

The general legal characteristics of war crimes will allow to comprehensively study the indicated acts, to understand their essence, which in turn will facilitate and improve the quality of criminal qualification of criminal offenses against performing the established procedure of active service. Moreover, the need to form the general legal characteristics of war crimes is due to the fact that the sphere of public relations related to active service is intersectoral. This means that it is simultaneously regulated by the norms of different branches of law. As a result, the criminal and legal norms determining the corpus delicti of military criminal offenses according to the level of certainty are usually blanket. In other words, the established procedure for active service is determined not in the provisions of the Articles of the Special Part of the Criminal Code (hereinafter, the CC) of Ukraine, but in the provisions of other regulatory legal acts. In this context, it is important to find out the main features belong to war crimes and to characterize them by determining specific features of their regulation not only in criminal, but also in other branches of law. 
While exploring the concept of a military offence, M. Piddubna (2020) concludes that a military offence is a guilty, socially dangerous, unlawful and punitive act consisting of violating rules of armed conflicts of international and non-international nature established by the basic principles of international law ius cogens, international humanitarian law, and the criminality of which is determined by acts of international criminal law.

War crimes are the most serious criminal offenses in the criminal legislation, which are classified as criminal offenses against humanity and human dignity and are also considered one of the international criminal offenses whose incriminations have arisen from international conventions. In their characteristics, war crimes are related to violations of the rules of international law during warfare, armed conflict and occupation, and the consequences of these crimes are usually related to a larger number of injured persons. Precisely because war crimes are violations of international law and international conventions, all democratic and legal states similarly regulate the crime of war crimes (Jug, 2018, pp. 601-602).

The Article 401 of the CC of Ukraine provides a legislative interpretation of military criminal offenses, namely:

«Servicemen of the Armed Forces of Ukraine, the Security Service of Ukraine, the State Border Guard Service of Ukraine, the National Guard of Ukraine and other military groups formed in accordance with the laws of Ukraine, the State Special Transport Service, the State Special Communications and Information Protection Service of Ukraine, as well as other persons specified by law, shall be liable under the respective Articles of this Section».

However, it should be noted that the domestic interpretation of war crimes differs from their interpretation in international, in particular, criminal law. According to international standards, to classify illegal actions as war crimes, they must contain two main elements: (i) a contextual element: "the action took place in the context of international/noninternational armed conflict and was related to it"; (ii) mental element: intention and knowledge of both the individual act and the contextual element (Office on Genocide Prevention and the Responsibility to Protect). In this case, "war crimes are acts contrary to the Law on International Armed Conflicts (LOIAC) and lead to criminal liability of persons who have committed prohibited acts" (Dinstein, 2016).

In fact, the legislator clearly states that all war crimes are defined in the XIX Section of the CC of Ukraine. Moreover, the object and subject of encroachment: the procedure established by law for performing active service and persons who are the subjects of these illegal acts are among the main features of war crimes. Therefore, providing the general legal 
characteristics of war crimes, first of all it is necessary to determine specific features of such features of the specified offenses as active service; the established procedure for performing active service; military personnel, as well as persons liable to military duty and personnel with reserve obligations during the battle assembly as subjects of the crime.

Active service in accordance with the Article 2 of the Law of Ukraine "On General Military Duty and Military Service" (Law of Ukraine of 25 March 1992) is public service of a special nature, which consists in the professional activities of citizens of Ukraine (except as provided by law), foreigners and stateless persons suitable for it due to health and age related to the defense of Ukraine, its independence and territorial integrity. Active service is understood as an institution of public service, which, according to R. Botvinova (2017, pp. 129-130), has the following characteristics:

(i) Carried out by a specific organization established by the state: the military organization of the state (sometimes it is called the army, armed forces).

(ii) The state determines the procedure and conditions of entry (involvement) into the military organization, stay in it and withdrawal from it.

(iii) It is assigned to protect the state from external encroachment by special military methods, involving the use of means of armed fight.

(iv) The state determines the internal arrangement of the military organization, the procedure for its management, the appointment of leaders and the establishment of differences between its members from the rest of the population of the country.

(v) Financed from the state budget.

O. Saynetskyy (2013, p. 215) offers to single out such specific features of active service as a constant risk to life and health due to the fact that military personnel can take part in military conflicts, hostilities; the way of life of military personnel is a detailed regulated legal regime, which extends not only to the time of service, but also to the time out of service, i.e. a member of the armed forces is "always" on service; members of the armed forces are subject to increased legal liability and they are prosecuted in a special manner regulated by special norms (service regulations); members of the armed forces are restricted in a number of rights and freedoms in order to ensure impartial and effective performance of assigned tasks.

It is noticeable from the above that active service has specific properties, which totally determine the legal status of the specified institution. It should be emphasized that the concept of active service is ambiguous, since it is used to denote both military duty and a type of public service (Saynetskyy, 2013, p. 211). Active service, like any legal institution, has the features that characterize and distinguish it from others. 
One of the main features characterizing active service is the established procedure regulated by law. Accordingly, violation of this procedure leads to legal consequences, in particular criminal prosecution. Therefore, the general legal characteristics of war crimes necessarily include such an important element as the established procedure for performing active service. We are talking about specific features of involvement, performance and discharge from active service (Kurtmollaiev, et al., 2017, p. 89). At the same time, these specific features cannot be clarified without defining the system of legal regulation of military service, which directly indicates the interdependence of the specified features.

War crimes are criminally punishable socially dangerous acts that violate the procedure established by law for active service. At the same time, it is noteworthy that war crimes are related to active service and discipline, and which harm the legal interests of military personnel by their nature, provided that they do so with full respect for judicial guarantees (AndreuGuzmán, 2005).

The criminal legislation of Ukraine, while interpreting the concept of military criminal offenses, does not emphasize the procedure of which type of active service is violated. By means of a logical analysis of the provisions of Chapter XIX of the CC of Ukraine, it can be concluded that they relate to active service in general, as a generalizing concept. The specific type of service, whose procedure of performance is violated, is defined in certain Articles of the specified Section of the law on criminal liability. In particular, according to the Article 6 of the Law of Ukraine "On General Military Duty and Military Service" we distinguish the following types of active service: compulsory military service; conscription national service during mobilization for a special period; soldier's military service under the contract; noncommissioned officers and warrant officer's military service under the contract; military service (training) of cadets of higher military educational institutions, as well as higher educational institutions, which have military institutes, faculties of military training, departments of military training, divisions of military training; officer's military service under the contract; conscription national service of officers; conscription national service of part-time servicemen during a special period. Accordingly, the procedure of performing active service may be somewhat clarified and differ depending on the type of active service, which means that the mandatory and optional elements of certain types of war crimes will also be slightly different. The procedure for performing active service is characterized by the following main elements. First, citizens who enlisted in the military on a contract or conscription basis take the Military Oath of Allegiance to the Ukrainian people. Secondly, persons who serve in the military are awarded 
military ranks. Thirdly, it is mandatory to observe military discipline during military service, the duties of military personnel, as well as persons liable to military duty and personnel with reserve obligations during the training (testing) and special assembly. In particular, military discipline is the impeccable and strict observance of the procedure and rules established by the statutes of the Armed Forces of Ukraine and other legislation of Ukraine by all members of the armed forces (On Disciplinary Regulations of the Armed Forces of Ukraine, 1999). Another integral element of active service is the subject of its performance, specific features of which determine the features of a special subject of war crimes. In particular, it is necessary to distinguish not only the personal traits of the offender among the features of active service, and hence war crimes, but also the status of the military formation, where the subject of the crime serves. The specified requirement is fully established by international standards for the characteristics of active service (Aurel, 2015, pp. 319-371). As an example, the U.S. Armed Forces system in the United States of America is represented by five services ${ }^{1}$, which, in turn, consist of two separate components, reserve and active (Halvorson, 2010, p. 2). President Donald J. Trump signed into law legislation creating the first new armed service since 1947, the U.S. Space Force. "Space is the world's newest warfighting domain", Trump said at Andrews (U.S. Department of Defense News, 2019).

According to the criminal legislation of Ukraine, the subjects of military criminal offenses are military personnel, persons liable to military duty and personnel with reserve obligations during the battle assembly. Thus, the legislator clarifies in part 2 of the Article 401 of the CC of Ukraine that:

«Responsibility under the relevant Articles of this Section is spread to military personnel of the Armed Forces of Ukraine, Security Service of Ukraine, State Border Guard Service of Ukraine, National Guard of Ukraine and other military formations formed under the laws of Ukraine, State Special Transport Service, State Service of Special Communication and Information Protection of Ukraine, as well as other persons specified by law».

That is, it indicates not only the status of an individual who is a subject in this category of crimes, but also provides the list of formations (although not exhaustible), where a member of the armed forces commits illegal acts while his/her active service.

\footnotetext{
${ }^{1}$ The term "armed forces" means the Army, Navy, Air Force, Marine Corps, Space Force, and Coast Guard (10 U.S. Code $\S 101$, Definitions).
} 
Interpretation of the terms "military personnel", "persons liable to military duty" and "personnel with reserve obligations" is provided in the Article 1 of the Law of Ukraine "On General Military Duty and Military Service" (1992); according to the provisions of those terms, they should be understood as follows:

(i) Persons serving in the military.

(ii) Persons who are in reserve to be recruited by the Armed Forces of Ukraine and other military formations for a special period, as well as to perform works to guarantee the state defense.

(iii) Persons who serve in the military reserve of the Armed Forces of Ukraine and other military formations and are assigned for their recruitment in peacetime and in special periods.

However, the Article 2 of the Law of Ukraine "On General Military Duty and Military Service" states that citizens of Ukraine, foreigners and stateless persons may perform active service. In particular, active service by citizens of Ukraine is carried out voluntarily (under contract) or under drafting; foreigners and stateless persons - voluntarily (under contract) in positions to be replaced by military personnel of soldiers, noncommissioned officers and warrant officers of the Armed Forces of Ukraine. At the same time, citizens of Ukraine, foreigners and stateless persons performing active service belong to military personnel. Foreigners and stateless persons who in accordance with the law perform active service in the Armed Forces of Ukraine are also equated to military personnel in accordance with the Article 1 of the specified Law. The status of a member of the armed forces is confirmed by an identity document (On Regulations About Active Service of Citizens of Ukraine in the Armed Forces of Ukraine, 2008).

\section{CONCLUSIONS}

1. Thus, despite the fact that war crimes are the criminal and legal category, their features are regulated along with criminal law by a number of regulations that determine the legal principles of active service and the procedure for performing active service. Therefore, it is appropriate to talk not just about criminal and legal, but about the general legal characteristics of war crimes, since it will ensure the proper criminal and legal protection of the procedure of active service, as well as timely detection of war crimes and their effective pre-trial investigation.

2. War crimes encroach on the procedure established by law for performing active service. The subjects of such illegal actions are military 
personnel, persons liable to military duty and personnel with reserve obligations during the battle assembly.

3. The general legal characteristic of war crimes is formed taking into account criminal and legal features of the specified criminal offenses and defines specific features of active service; the established procedure for performing active service; military personnel, persons liable to military duty and personnel with reserve obligations during the battle assembly as subjects of the crime.

4. The procedure of active service differs depending on the type of active service, and therefore, the mandatory and optional elements of certain types of war crimes also differ.

\section{REFERENCES}

Aaronson, E., \& Shaffer, G. (2021). Defining Crimes in a Global Age: Criminalization as a Transnational Legal Process. Law \& Social Inquiry, 46 (2), 455-486. Doi: 10.1017/lsi.2020.42

Akimov, M. (2018). Criminal Law Protection of Person's Freedom: Problems and Solutions. Public Security and Public Order, 20, 9-18.

Akimov, M. (29-XI-2019). Regarding the Proper Criminal and Legal Assessment of Violations of the Laws and Customs of War. In Military Education and Science: Present Time and Future. Abstracts of the XV International Scientific and Practical Conference, pp. 5-9. Kyiv, Ukraine.

Andreu-Guzmán, F. (2005). Military Jurisdiction and International Law. International Jurisprudence and Doctrine on Human Rights [II]. International Commission of Jurists.

Aurel, S. (2015). The Status of Armed Forces in Public International Law. In A. Orakhelashvili (Ed.), Research Handbook on Jurisdiction and Immunities in International Law, 319-371. Edward Elgar Publishing.

Botvinov, R. (2017). Military Service of Ukraine as an Institute of Public Service. Public Administration and Local Government, 3 (34), 128-134.

Cheah, W. (2018a). Dealing with Desertion and Gaps in International Humanitarian Law: Changes of Allegiance in the Singapore War Crimes Trials. Asian Journal of International Law, 8 (2), 350-370. Doi: 10.1017/S2044251316000308

Cheah, W. (2018b). Desertion and Gaps in International Humanitarian Law: Dealing with Changes of Allegiance in the Singapore War Crimes Trials - Addendum. Asian Journal of International Law, 8 (2), 371-371. Doi:

$10.1017 / \mathrm{S} 2044251317000017$ 
Chehtman, A. (2018). Revisionist Just War Theory and the Concept of War Crimes. Leiden Journal of International Law, 31 (1), 171-194. Doi: $10.1017 /$ S0922156517000498

Dinstein, Y. (2016). War Crimes, Orders, Command Responsibility and Defenses. In Y. Dinstein, The Conduct of Hostilities Under the Law of International Armed Conflict, pp. 298-331. Cambridge University Press.

Fenrick, W. J. (1999). Should Crimes Against Humanity Replace War Crimes? Columbia Journal of Transnational Law, 3 (37), 767-785.

Fenrick, W. J. (2015). Military Self-Interest in Accountability for Core International Crimes. International Review of the Red Cross, 97 (900), 1503-1506. Doi: $10.1017 / \mathrm{S} 1816383116000278$

Halvorson, A. (2010). Understanding the Military: The Institution, the Culture, and the People. Information for Behavioral Healthcare Specialists Working with Veterans and Service Members. Samhsa.

Jug, J. (2018). Liability for Damages and Reparation for Harm Caused by War Crimes. Zbornik Pravnog Fakulteta Sveučilišta u Rijeci, 39 (1), 601-628. Doi: https://doi.org/10.30925/zpfsr.39.1.20

Karpenko, M. I. (2019). War Crimes: Issues of Theory, Legislation and Practice. [Monograph. Under Gen. Ed. of V. K. Matviichuk]. HEI National Academy of Management.

Karytonov, S. O. (2019). Military Crimes: Meaning, System and Qualification Problems [Thesis for Doctor Degree]. Yaroslav Mudryi National Law University, Kharkiv, Ukraine.

Koval, V. (2021). Administrative and Legal Status of Servicemen in Ukraine under the Legal Regime of Martial Law [Dissertation for the Degree of Doctor of Philosophy]. Karazin Kharkiv National University, Kharkiv, Ukraine.

Kulkina, Y. S. (2016). Comparative Characteristic of Military Crimes in Ukraine and Foreign Countries (by the Example of the Art. 414 of the Criminal Code of Ukraine). Forum Prava, 5, 103-109.

Kurtmollaiev, A. E., Kushnir, M. V., \& Koropatnik, I. M. (2017). The Legal Adjusting of Passing of Military Service is in the Armed Forces of Ukraine in a Special Period. Juridical Scientific and Electronic Journal, 4, 87-89.

Kurys, V. Z. (29-XI-2019). Legal Guaranteeing of Military Formations in Ukraine. In Military Education and Science: Present Time and Future. Abstracts of the XV International Scientific and Practical Conference, pp. 38-42. Kyiv, Ukraine.

Kushnir, M. V. (2018). Theoretical and Legal Principles of Administration of Active Service in the Armed Forces of Ukraine. Law and Society, 3 (2), 133-140.

Kuznetsov, V. V. (2015). Criminal Law Protection: Problem Definition. Uzhhorod National University Herald. Series: Law, 30 (2), 107-110. 
Lutsiv, M. Z. (2020). The Specificity of the Pre-Trial Investigation of Crimes Against the Established Order of Military Service (Articles 407-409 of the Criminal Code of Ukraine). PHD, National Law University.

Marchesi, D. (2021). The War Crimes of Denying Judicial Guarantees and the Uncertainties Surrounding Their Material Elements. Israel Law Review, 54 (2), 174-204. Doi: 10.1017/S0021223721000030

Matviichuk, V. (2008). Criminal and Legal Protection of the Environment: Problems of Legislation, Theory and Practice [Thesis of the Doctor's Dissertation]. V. M. Koretsky National Academy of Sciences of Ukraine, Kyiv, Ukraine.

Nikolaienko, T. B. (2019). Theoretical and Legal Principles of Infliction and Execution of the Special Punishments to Servicemen [Thesis on Gaining Scientific Degree of the Doctor of Juridical Science]. State Research Institute of the Ministry of Internal Affairs of Ukraine, Kyiv, Ukraine; University of the State Fiscal Service of Ukraine, Irpin, Ukraine.

Onyskiv, A. (2016). The Composition Ratio of Crimes Against Military Service Order with Other Corpus Delicti. Journal of the National Prosecution Academy of Ukraine, 4, 72-78.

Pashchenko, Y. M. (2021). Criminological Features and Prevention of Violent Crime Among Servicemen [Thesis Doctor of Philosophy]. Karazin Kharkiv National University, Kharkiv, Ukraine.

Piddubna, M. (2020). Implementation of International Criminal Law Norms on Military Offences into Criminal Code of Ukraine [Thesis for a Candidate Degree in Law]. Ivan Franko National University of Lviv, V. M. Koretsky Institute of State and Law of the National Academy of Sciences of Ukraine, Kyiv, Ukraine.

Ross, A. (1975). On Guilt, Responsibility and Punishment. Stevens \& Sons Limited.

Sadova, T. S. (2021). On the Question of the Relationship of War and Military Crimes in International and National Law. Constitutional State, 42, 220-228. Doi: https://doi.org/10.18524/2411-2054.2021.42.232433

Saynetskyy, O. (2013). The Essence and Characteristics of Military Service. Public Law, 3 (11), 210-216.

Shakhrai, B. M. (29-XI-2019). The Role of Judicial Agencies in Guaranteeing the Rights and Freedoms of Military Personnel and Keeping Public Order in the Armed Forces and Other Military Formations of Ukraine. In Military Education and Science: Present Time and Future. Abstracts of the XV International Scientific and Practical Conference, pp. 87-91. Kyiv, Ukraine.

Sheshko, S. V. (29-XI-2019). Legal Principles for Functioning of National Security and Defense Sector. In Military Education and Science: Present Time and Future. Abstracts of the XV International Scientific and Practical Conference, pp. 9196. Kyiv, Ukraine.

Sokurenko, V. V. (2016). Public Administration of the Defense Sphere in Ukraine [Thesis for a Doctoral Degree]. Yaroslav Mudryi National Law University, Kharkiv, Ukraine. 
Tereshchuk, V. M. (29-XI-2019). Problems of Improving the Legal Status of the Subjects of Public Administration of the National Security and Defense Sector of Ukraine. In Military Education and Science: Present Time and Future. Abstracts of the XV International Scientific and Practical Conference, pp. 8082. Kyiv, Ukraine.

Ukraine (1992). On General Military Duty and Military Service, Law of Ukraine of 25 March 1992, No. 2232-XII. Verkhovna Rada of Ukraine.

Ukraine (1996). Constitution of Ukraine, Law of Ukraine of 28 June 1996, No. 254k/96VR. Verkhovna Rada of Ukraine.

Ukraine (1999). On Disciplinary Regulations of the Armed Forces of Ukraine, Law of Ukraine of 24 March 1999, No. 551-XIV. Verkhovna Rada of Ukraine.

Ukraine (2001). Criminal Code of Ukraine, Law of Ukraine of 5 April 2001, No. 2341-III. Verkhovna Rada of Ukraine.

Ukraine (2008). On Regulations About Active Service of Citizens of Ukraine in the Armed Forces of Ukraine, Decree of the President of Ukraine of 10 December 2008, No. 1153/2008. Verkhovna Rada of Ukraine.

United Nations (s/d). Definitions. War Crimes. Office on Genocide Prevention and the Responsibility to Protect. https://www.un.org/en/genocideprevention/warcrimes.shtml

U.S. Department of Defense News (20-XII-2019). Trump Signs Law Establishing U.S. Space Force. U. S. Department of Defense. https://www.defense.gov/News/News-Stories/Article/Article/2046035/trumpsigns-law-establishing-us-space-force/

Voznyk, M. V. (29-XI-2019). Certain Aspects of Improving Military Law of Ukraine. In Military Education and Science: Present Time and Future. Abstracts of the XV International Scientific and Practical Conference, pp. 9-12. Kyiv, Ukraine.

Yaremko, G., Ivanova, N., Mandrychenko, Z., \& Gorpyniuk, O. (2021). Criminal and Legal Protection of National Security: Problems of Systematization of Crimes. Amazonia Investiga, 10 (47), 207-215. Doi: https://doi.org/10.34069/AI/2021.47.11.21

Zhurovets, V. (29-XI-2019). Legal Guaranteeing of Military Discipline and Public Order. In Military Education and Science: Present Time and Future. Abstracts of the XV International Scientific and Practical Conference, pp. 22-27. Kyiv, Ukraine. 